\title{
MEDIA DAN POLITIK (Mencari Independensi Media Dalam Pemberitaan Politik)
}

\author{
Vellayati Hajad \\ Program Studi Ilmu Komunikasi, UniversitasTeuku Umar \\ Email:vellayati.hajad@gmail.com
}

\begin{abstract}
This article explains about the relation of media and politics and how the position of how the media position in Indonesian politics. Shoemaker and Reese have two approaches see the media, namely passive and active. The passive approach occurs when the media represent reality without distortion. Active approach is when the media come to frame social reality into the reality of media. The second approach is what makes media are not neutral and do tend to be biased in their reporting because the media no longer represent the event as a whole but with some viewpoints that are considered attractive. It is often also referred to as media manipulation. The media in a democracy should be able to independently and not closer to the government and the market.
\end{abstract}

\section{Keywords: Media, Politics and Democratization}

\section{PENDAHULUAN}

Tulisan ini secara umum akan menggambarkan bagaimana signifikannya aspek pertemuan antara politik dan media. Hal tersebut dapat dilihat dari berbagai riset tentang pengaruh media terhadap sikap, opini, dan keyakinan individu terhadap proses politik yang berlangsung. Politik dipahami sebagai kompetisi atau pertarungan kepentingan antara kelompok-kelompok di dalam masyarakat untuk memperoleh sumberdaya yang terbatas (limited resourced). Media dapat dipahami sebagai sebuah titik pertemuan dari banyak kekuatan dan kepentingan (Koike: 2002). Media massa dalam hal ini menjadi sangat efektif untuk melakukan propaganda (mempengaruhi) masyarakat misalnya digunakan untuk self marketing ketika kampanye politik yaitu untuk mencari suara atau untuk membangun kekuatan politik yang diorientasikan pada kekuasaan.

Media massa berpengaruh terhadap kampanye politik (media cetak maupun elektronik) karena dalam menentukan keputusan politik, masyarakat akan selalu membutuhkan referensi. Melalui berita-berita yang disiarkan, media secara tidak langsung telah memberikan referensi kepada masyarakat untuk mempengaruhi keputusan politiknya. Semakin sering berita tersebut diberikan, maka akan semakin besar pengaruh yang akan didapatkan oleh masyarakat. Media massa menentukan agenda publik dan peran media adalah mendorong dukungan publik terhadap kepentingan-kepentingan tertentu yang mendominasi pemerintah dan masyarakat. Peningkatan akses terhadap media tersebut pada akhirnya akan berimplikasi terhadap peningkatan kepercayaan masyarakat terhadap pesanpesan yang disampaikan media. Dengan demikian, media akan menjadi semakin kuat dalam mempengaruhi dan semakin efektif jika orang-orang yang memiliki kepentingan menggunakannya untuk melakukan propaganda-propaganda tertentu.

Media memainkan peranan penting dalam gerakan yang terjadi di negara -negara Asia Tenggara seperti yang terjadi di Filipina pada tahun 1986 ketika berlangsung gerakan People Power yaitu sebuah gerakan untuk menjatuhkan Marcos dari kursi presiden. Begitu 
pula yang terjadi di Thailand pada tahun 1992 yang terkenal dengan Peristiwa Mei. Rakyat Thailand berhasil menggulingkan pemerintahan Suchinda Kraprayoon. Sedangkan di Indonesia pada tahun 1998, gelombang demonstran dari kalangan mahasiswa juga berhasil menjatuhkan Presiden Soeharto (McCargo: 1999). Dalam kajian demokratisasi, press independent membuka peluang bagi terbukanya kebebasan, perubahan politik, dan mendukung transisi demokrasi serta meruntuhkan rezim yang otoritarian. Media juga dapat bertindak sebagai agen perubahan. Neumann menjelaskan bahwa kebebasan memegang peranan penting di Asia Tenggara, khususnya dalam proses liberalisasi politik yang berhubungan dengan munculnya pers yang lebih terbuka dan kritis (Neumann: 1998). Kondisi ini sangat berbeda bila dibandingkan dengan masa sebelum jatuhnya Soeharto.

Media massa pada era pasca pemerintahan Soeharto diwarnai oleh kuatnya dominasi penguasa dalam hal pemberitaan dan penyampaian informasi kepada masyarakat. Media pada akhirnya adalah perpanjangan tangan dan penyalur kepentingan penguasa. Bahasa yang digunakan oleh media adalah bahasa politik yang bermakna ganda yang bertujuan untuk memperdaya masyarakat demi mengukuhkan eksistensi penguasa. Berbagai tindakan represif sering dilakukan oleh pemerintah terhadap individu atau kelompok yang berani untuk menyuarakan aspirasi politiknya. Persoalan politik dan komunikasi telah menjadi pusat perhatian di Indonesia. Namun, setelah jatuhnya pemerintahan Soeharto pada 1998 media memperoleh kebebasan dari kontrol dan pembredelan yang dulu kerap dilakukan oleh pemerintah Orde Baru. Kebebasan ini dirayakan dengan meningkatnya jumlah media di Indonesia pasca-1998.

\section{TINJAUAN PUSTAKA}

\section{Media Sebagai Aktor Politik}

Media massa memiliki peran yang sangat penting dan strategis dalam pembentukan opini publik, karena media massa mampu mempengaruhi sikap masyarakat terhadap suatu peristiwa tertentu. Bahkan terkadang membuat audience tidak sadar akan peristiwa yang sesungguhnya terjadi. Menurut McQuail (2002) peranan media massa memiliki kemampuan sebagai alat ideologi karena mampu menarik dan mengarahkan perhatian, membujuk pendapat dan anggapan, mempengaruhi sikap, memberikan status dan mendefinisikan legitimasi serta mendefinisikan realitas. Dalam hal ini sering kali media massa dijadikan sebagai alat berbagai macam kepentingan dalam kehidupan masyarakat sehingga ia menjadi perpanjangan tangan dari berbagai elemen masyarakat. Senada pula menurut McLuhan sebagaimana dikutip oleh Littlejohn (2002), media merupakan perpanjangan dari pikiran manusia dan beranggapan bahwa kecenderungan utama dalam periode sejarah manapun adalah merupakan suatu pengaruh dari media yang berkuasa pada saat itu.

Dengan kata lain apa yang terjadi dan apa yang nampaknya penting dalam periode sejarah ditentukan oleh media. Kutipan ini menguatkan bukti bahwa peranan media massa dalam kehidupan sosial masyarakat sangat penting sekali. Dalam pandangan konstruktivisme, menurut Bennet, sebagaimana dikutip oleh Hidayat (1997), media massa bukan hanya sebagai saluran pesan, tetapi sebagai subyek yang mengkonstruksi realitas, pandangan, bias dan pemihakannya. Di sini media massa dipandang sebagai agen konstruksi sosial yang mendefinisikan realitas, pandangan ini menolak pendapat yang menyatakan bahwa media merupakan tempat saluran yang bebas. Begitu pula berita yang di baca dan didengar dari media massa bukan hanya menggambarkan realitas, dan menunjukkan sumber berita tetapi juga konstruksi dari media itu sendiri. Hal itu bukan 
menunjukkan realitas yang sebenarnya, tetapi menggambarkan bagaimana media ikut berperan dalam mengkonstruksi realitas.

Berita yang muncul dalam pikiran manusia itu bukan suatu peristiwa, tapi lebih merupakan sesuatu yang diterjemahkan oleh akal dan pikiran manusia setelah peristiwa itu terjadi. Berita tidak identik dengan fakta peristiwa tetapi melainkan sebuah upaya untuk merekonstruksi fakta dalam kerangka inti peristiwa. Berita pada kenyataannya adalah hasil konstruksi realitas dengan menggunakan bahasa sebagai alat dasar, dan bahasa dapat menentukan cerminan seperti apa yang akan dikemas tentang peristiwa yang sebenarnya. Konstruksi realitas sering menjadikan suatu peristiwa dengan menambahkan gambaran positif maupun gambaran yang negatif.

Berita adalah hasil dari konstruksi sosial yang selalu melibatkan pandangan, simbol dan nilai-nilai, bagaimana realitas dijadikan berita tergantung pada bagaimana fakta itu dipahami dan dimaknai. Apabila proses pemaknaan selalu menggunakan simbol unsur nilai-nilai tertentu maka mustahil berita merupakan wajah atau pencerminan dari suatu realitas itu sendiri, maka peristiwa yang sama bisa jadi menghasilkan berita yang berbeda karena adanya perbedaan cara melihat dalam hal ini cara membingkainya, namun perbedaan realitas itu pada akhirnya dianggap sesuatu hal yang wajar.

\section{Tabel 1 Bentuk dan Pengaruh Pemberitaan Media Terhadap Masyarakat}

\section{Bentuk Media}

Televisi

Surat Kabar

\section{Pengaruh Pada Masyarakat}

Televisi dengan karakteristik audio visualnya memberikan sejumlah keunggulan, diantaranya mampu menyampaikan pesan melalui gambar dan suara secara bersamaan dan hidup, serta dapat menayangkan ruang yang sangat luas kepada sejumlah besar pemirsa dalam waktu bersamaan. Contohnya melalui iklan.

Sebuah berita besar dalam surat kabar atau yang menjadi topik utama selalu ditempatkan di halaman depan dengan judul yang menarik dan membuat penasaran ditambah dengan foto yang mendukung. Contohnya surat kabar dengan sajian berbentuk kata tercetak atau bentuk visual berupa foto berita, lambang partai politik, atau karikatur memiliki pengaruh yang besar dalam kampanye politik.

Media menurut banyak kalangan adalah aktor politik yang penting dalam pertarungan politik di Indonesia. Alasannya adalah media sebagai sebuah institusi dan aktor politik memiliki hak-hak. Selain itu, media dapat memainkan berbagai peran politik, diantaranya mendukung proses transisi demokrasi, dan melakukan oposisi. Sebagaimana disinyalir oleh Cook, bahwa hal ini telah menjadi perhatian penting pada masyarakat Barat, di mana para jurnalis telah berhasil mendorong masyarakat untuk tidak melihat mereka sebagai aktor politik, sedangkan para pakar politik juga telah gagal untuk mengenali media sebagai sebuah institusi politik (Cook: 1998).

Dalam buku Why don't we call journalists political actors? Cook (1998) mengatakan bahwa para jurnalis berusaha meyakinkan masyarakat bahwa jurnalis bukan merupakan aktor politik. Selain itu pakar politik melihat konstribusi politik dari media dan mengabaikan fakta bahwa media adalah sebuah institusi. Dengan kata lain, para jurnalis 
juga telah berhasil untuk meyakinkan kalangan akademisi dan para peneliti bahwa mereka (jurnalis) bukan aktor politik. Media juga dianggap fire-fighting, yaitu membantu dalam menentukan hasil dari perubahan politik dan sosial dramatik yang terjadi di saat-saat krisis.

Hal ini dapat dilihat dari peran media dalam menggulingkan rezim Marcos di Filipina di tahun 1986, atau dukungan yang ditunjukkan pers pada demonstrasi prodemokrasi pada bulan Mei1992 di Bangkok. Pers merupakan agen perubahan (agent of change) atau agen stabilitas dalam rezim otoriter, sebagai agen pengendali dalam demokrasi liberal (seperti di Jepang pada tahun 1970-an), dan agen perubahan dalam masyarakat di saat terjadinya transisi politik (sepertidi Korea Selatan pada tahun 1987). Dalam negara berkembang seperti Indonesia, pemusatan peranan politik media telah diakui dalam proses nation building.

Tiga aktor dalam politik media ialah politisi, jurnalis, dan masyarakat yang digerakkan oleh kepentingan khusus. Bagi politisi, tujuan dari politik media adalah untuk mobilisasi dukungan publik yang diperlukan untuk memenangkan calon dalam pemilihan umum dan ketika sudah terpilih dapat membentuk program. Bagi jurnalis, tujuan politik media adalah untuk menciptakan berita baik dalam bentuk tulisan dan gambar yang dapat menarik perhatian banyak orang sedangkan bagi masyarakat tujuan dari politik media adalah untuk mengawasi politik dan menjaga kebijakan dan program politisi agar tetap akuntabel dan transparan. Hubungan antara ketiga aktor seringkali menciptakan ketegangan karena di satu sisi politisi menghendaki para jurnalis untuk bertindak sebagai pembawa berita yang netral dalam setiap pemberitaan (statemen dan rilis pers). Sementara para jurnalis tidak ingin menjadi tangan kanan pihak lain dan dikontrol oleh kepentingan manapun. Jika jurnalis membuat berita yang dikehendaki politisi atau bahkan hanya melaporkan berita politik yang sesuai dengan keinginan pembaca, maka jurnalisme (menurut para jurnalis) hanya akan menjadi profesi yang kurang menguntungkan dan kurang memuaskan bagi praktisinya, atau bahkan bukan lagi menjadi sebuah profesi.

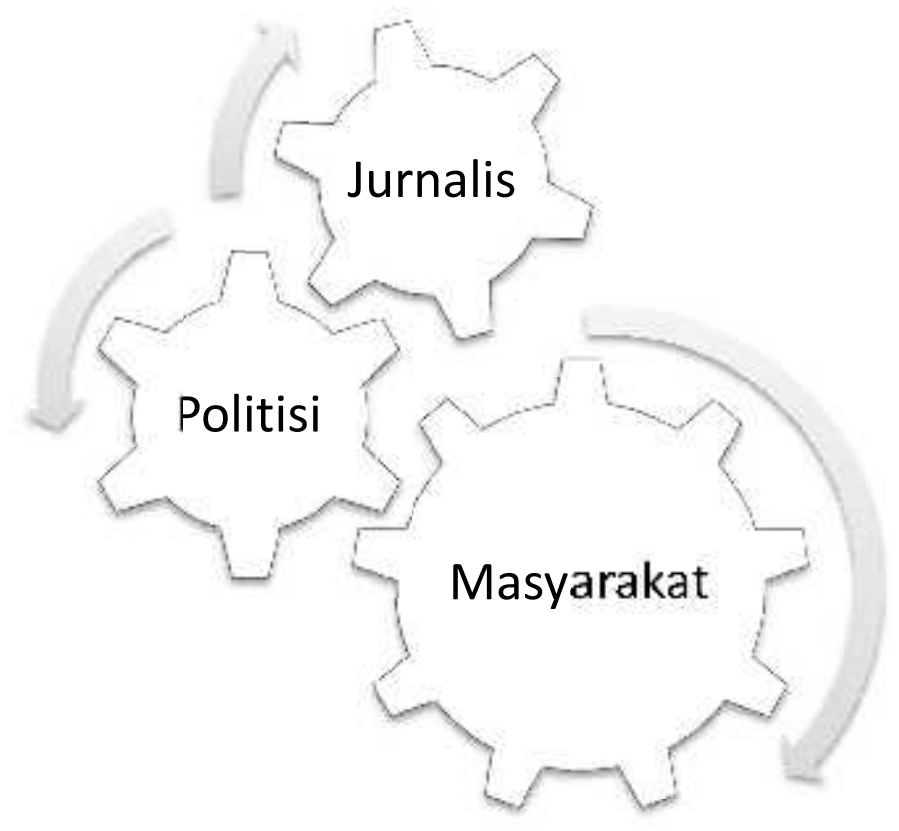

Gambar 1: Tiga Aktor Politik

Pada dasarnya pihak publik menginginkan untuk mengawasi jalannya politik dan menjaga agar politisi tetap akuntabel dengan upaya yang minimal. Dan dikarenakan adanya 
kejenuhan pihak politisi dan para jurnalis yang bersaing untuk mendapatkan perhatian publik dalam pasar yang kompetitif, publik cenderung mendapatkan bentuk komunikasi politik yang mereka inginkan. Namun ini tidak berlaku seluruhnya. Kepentingan yang telah melekat pada diri politisi untuk mengontrol muatan berita politik, berpadu dengan kepentingan jurnalis untuk membuat kontribusi yang independen dalam berita, akan menciptakan ketegangan dan distorsi yang cukup besar.

Media dalam kehidupan politik sering disebut sebagai pilar keempat demokrasi selain eksekutif, yudikatif, dan legislatif. Bahkan dalam bukunya yang berjudul $A n$ Introduction to Political Communication, Brian McNair (2003) mengatakan bahwa terdapat lima peran ideal media dalam mewujudkan kehidupan demokratis. Peran pertama media adalah memberikan informasi tentang apa yang terjadi, peran kedua adalah memberikan edukasi bagi masyarakat tentang hal yang terjadi di lapangan. Menurut McNair dituntut objektifitas jurnalis sebagai edukator dalam hal pemberitaan. Bahkan John Robert Hendricks dan Robert E. Denton juga mengatakan bahwa media berperan untuk membentuk, mengumpulkan, dan menyebarkan informasi agar masyarakat memahami isu politik dan memiliki keterikatan dengan politik. Peran media yang ketiga adalah sebagai wadah diskursus. Media menjadi peracik agenda politik yang memberikan informasi dan memilah isu yang pada akhirnya akan mempengaruhi opini publik. Peran media yang keempat adalah sebagai pemantau pemerintah (watch dog). Maksudnya adalah media juga memiliki peran untuk mengkritik pemerintah, baik itu kebijakan ataupun program-program yang dibuat oleh pemerintah. Peran kelima, McNair menyebutkan bahwa media juga berperan untuk mengadvokasi beberapa pandangan politik (persuasion) yaitu sebagai kanal partai politik untuk menyampaikan sudut pandangnya.

Bahasa politik media menurut Jurgen Habermas adalah is also a medium of domination and power. Artinya, bahasa (kata-kata yang digunakan) dapat merupakan alat dominasi ataupun kekuasaan. Menurut Mc Quail, secara umum media massa memiliki berbagai fungsi bagi masyarakat yaitu sebagai pemberi informasi, sebagai pemberian komentar atau interpretasi yang membantu pemahaman makna informasi, pembentukan kesepakatan, korelasi bagian-bagian masyarakat dalam pemberian respon terhadap lingkungan, transmisi warisan budaya, dan ekspresi nilai-nilai dan simbol budaya yang diperlukan untuk melestarikan identitas dan kesinambungan masyarakat (Yuniati: 2002).

\section{Indikator Independensi dan Netralitas}

Independensi yang mengusung objektivitas dan netralitas telah menjadi standar baku dalam dunia jurnalistik untuk menuntun kinerja mereka. Selain itu, objektivitas juga bertindak sebagai penanda bagi profesionalitas media (McQuail: 1992). Media yang profesional tentu akan menampilkan liputan-liputan media yang objektif dan netral sehingga memiliki tingkat independensi yang tinggi. Ini karena hanya media yang independen yang mampu membuat reportase peristiwa secara objektif. Sebaliknya, mediamedia yang tidak independen akan cenderung membuat laporan-laporan yang bias dan tidak objektif terhadap fenomena yang terjadi.

Menurut Walker Cronkite (2013) objektivitas dapat didefinisikan sebagai aktivitas melaporkan kenyataan atau fakta, semampu yang bisa dilakukan oleh wartawan tanpa terpengaruh oleh prasangka dan opini. Objektivitas sangat erat kaitannya dengan pemahaman secara kultural wartawan atas masyarakat di sekitarnya. Dengan kata lain, wartawan mesti independen dari faksi. Wartawan, bagaimana pun juga, harus independen dari pihak yang mereka liput (Kovach \& Rosenstiel: 2001). Dengan demikian wartawan bisa lebih obyektif dan independen dari kelas atau status ekonomi, dan juga independen 
dari ras, etnis, agama, dan gender penting untuk menghasilkan berita yang obyektif (Kovach \& Rosenstiel 2001). Namun demikian, objektivitas dapat diamati dari tiga aspek yang berbeda, yaitu nilai, proses dan bahasa (Maras: 2013).

Prosedur untuk memastikan independensi dan netralitas antara lain komitmen yang kuat untuk selalu memverifikasi informasi melalui metode yang obyektif. Aspek ketiga yang juga penting untuk mewujudkan objektivitas adalah bahasa. Bahasa adalah sarana menyampaikan fakta di dalam berita. Objektivitas adalah sejenis "permainan bahasa", yang merupakan strategi spesifik menampilkan kembali kejadian, fakta, dan detailnya (Maras: 2013). McQuail (1992) menguraikan beberapa indikator penting dalam melihat persoalan independensi (objektivitas) dan netralitas, diantaranya: ada tidaknya opini, unsur personalisasi, sensasionalisme, stereotype, juxtaposition atau linkage, dan akurasi dalam pemberitaan.

Unsur personalisasi dalam pemberitaan diartikan sebagai pandangan yang melihat pemilik atau aktor politik sebagai aktor utama/penting atau tunggal yang paling berpengaruh dalam sebuah peristiwa. Personalisasi dapat dilacak dengan melihat adatidaknya klaim peran yang berlebih-lebihan baik bernada positif maupun negatif terkait dengan pemilik atau aktor politik. Unsur personalisasi merupakan salah unsur penting (selain sensasionalisme, stereotype dan linkage) dalam menilai netralitas pemberitaan (media) (McQuail: 1992). Netralitas memiliki arti penting yang senada dengan keseimbangan namun lebih menekankan pada bagaimana informasi dipresentasikan.

\section{Berbicara Independensi Media Terhadap Pemberitaan Politik}

Independensi media adalah sebuah konsep yang sangat rumit. Menurut Meadow (1980) sebuah berita tidak mungkin objektif dan tidak mungkin bebas dari kepentingankepentingan tertentu. Sebuah berita tidak mungkin menyajikan seluruh fakta sosial dalam halaman surat kabar yang terbatas dan terdapat proses seleksi terhadap fakta-fakta yang disajikan namun tidak semua peristiwa layak untuk dijadikan berita. Dan berita politik memang dianggap dapat menjangkau berbagai lapisan masyarakat penikmat berita. Dapat dikatakan bahwa terdapat dua faktor yang menyebabkan hal tersebut dapat terjadi.

Faktor pertama adalah saat ini politik berada di era mediasi (politics in the age of mediation), yakni media massa, sehingga hampir mustahil kehidupan politik dipisahkan dari media massa. Oleh karena itu yang terjadi adalah para tokoh politik senantiasa berusaha menarik perhatian wartawan dan awak media agar meliput kegiatan politik yang mereka lakukan. Faktor kedua, peristiwa politik dalam bentuk tingkah laku dan pernyataan para aktor politik lazimnya selalu mempunyai nilai berita sekalipun peristiwa politik itu bersifat rutin belaka, seperti rapat partai atau pertemuan seorang tokoh politik dengan para pendukungnya (Ibnu Hamad: 2004). Secara umum independensi adalah ide bahwa wartawan harus bebas dari bentuk campur tangan apapun ketika menjalankan dan mempraktekan profesinya.

Di berbagai negara, pemilik media yang terbesar (umumnya pemilik stasiun televisi dan radio terkemuka) adalah pemerintah sendiri. Upaya yang perlu dijalankan untuk memperkuat independensi media dengan cara menjadikan media milik pemerintah atau yang dikendalikan oleh pemerintah milik swasta. Menurut William L. Rivers (2003) tidak ada media yang netral karena pers ataupun media akan selalu berpihak terutama pada kepentingan pemiliknya. Rivers juga mengatakan bahwa kebebasan pers yang berlaku di dunia adalah kebebasan pemilik pers (freedom for media owner)."Pemilik media masih bisa menempatkan berita yang penting untuknya -meskipun tidak terlalu penting untuk umum - di halaman pertama atau pada jam tayang utama (prime time). Sebaliknya berita tertentu bisa saja ditahan atau batal dimuat. Hal ini membuktikan, pemilik masih berkuasa" 
(Rivers: 2003).Dengan demikian independensi jurnalis atau wartawan akan terpasung oleh kepentingan pemilik atau pemodal yaitu dengan menyelaraskan konten pemberitaan dengan visi, misi dan kebijakan redaksi tempat jurnalis bekerja.

Fenomena pemusatan kepemilikan media massa pada sekelompok orang seakan telah menjadi hal lumrah di Indonesia. Hasil penelitian Centre for Innovation Policy and Governance (CIPG) dan Hivos tentang "Mapping the Landscape of the Media Industry in Contemporary Indonesia" mencatat 12 kelompok besar yang mempengaruhi pangsa pasar media massa di Indonesia. Mereka adalah Global Media Communication, Media Nusantara Citra (MNC) milik Hary Tanoesoedibjo, Jawa Pos Group milik Dahlan Iskan, Kompas Gramedia milik Jacob Oetama, Mahaka Media miliki Erick Thohir, Elang Mahkota Teknologi milik keluarga Sariaatmadja, CT Group milik Chaerul Tandjung, Visi Media Asia milik kelompok Bakrie, Media Group milik Surya Paloh, MRA Media milik keluarga Soetowo, Femina Group milik Pia Alisjahbana, Tempo Inti Media milik Yayasan Tempo, dan Berita Satu Media Holding milik Lippo Group.

Hampir semua kelompok besar tersebut memiliki perusahaan media massa dengan berbagai macam bentuk, mulai dari cetak, penyiaran, hingga portal news online. Berbagai kelompok besar media massa itu tidak cuma memiliki kepentingan bisnis, tapi juga berkaitan erat dengan kepentingan politik para pemilik modal. Sebagai contoh Aburizal Bakrie, selaku pemilik Visi Media Asia, merupakan mantan Ketua Umum Partai Golkar. Pemilik Media Group, Surya Paloh, adalah pendiri sekaligus Ketua Umum Partai NasDem. Sedangkan Hary Tanoesoedibjo, pemilik MNC, merupakan Pendiri Partai Perindo.

Independen atau tidaknya media juga dapat dilihat dari berpihaknya sebuah media terhadap satu kekuatan politik tertentu. Secara sederhana dapat dikatakan bahwa jika media membuat wacana yang berisi pembelaan terhadap sebuah kekuatan politik (partai politik) maka dapat dikatakan bahwa media tersebut memiliki tujuan politik dan ideologis dibalik berita yang dibuat. Jika sebuah media lebih mengutamakan peristiwa yang menonjol (kontroversial) dari sebuah partai politik tanpa pembelaan ideologis terhadap kekuatan politik berarti media lebih berorientasi pada pasar atau keuntungan ideologis. Jika media menyampaikan berita tanpa ada pretensi ideologis dan ekonomis maka dapat dikatakan media tersebut berada pada posisi media yang idealis dan independen (Hamid: 2004).Ketika media mendukung salah satu kandidat atau partai (media endorsement). Terlepas dari keadaan ideal tersebut, liputan-liputan politik di media akan menjadi cenderung bias, subyektif dan partisan, alih-alih obyektif atau tidak berpihak. Bias muncul karena realitas sebenarnya ditampilkan menjadi realitas media yang telah dikonstruksi oleh jurnalis saat membuat berita.

Temuan berbagai penelitian menunjukkan bahwa kepemilikan media massa oleh satu pengurus partai politik yang ikut bertarung sudah menunjukkan kecenderungan untuk mendukung kegiatan partai politik yang diusung oleh pemiliknya. Setidaknya pemberitaan yang menekankan kegiatan pemilik media dan afiliasinya terlihat memiliki porsi yang lebih banyak dibandingkan dengan pemberitaan saingan politiknya. Upaya media untuk menjaga kode etik, independensi dan netralitas tetap diusahakan oleh para pekerjanya. Namun, intervensi dari pemilik terkadang terjadi sehingga menimbulkan kesan media berpihak pada satu sisi secara terbuka. Hasil wawancara menunjukkan bahwa intervensi adalah salah satu yang menimbulkan ketegangan di kalangan para pekerja media dengan pemiliknya walaupun mereka yang menjadi narasumber wawancara tidak pernah mengakuinya secara terbuka.

Noam Chomsky dalam teorinya mengemukakan bahwa media adalah bagian dari propaganda rezim. Dengan kata lain, independensi murni media tidak mungkin ada. Namun, secara normatif, masyarakat tetap mengharapkan agar media di Indonesia tidak 
boleh memihak. Namun pada perkembangannya, muncul teori baru yaitu populis partnership yaitu yang ditandai dengan pembelahan media. Hal ini dapat dilihat pada Pemilihan presiden 2014 lalu. Beberapa media secara terang-terangan menunjukkan dukungannya kepada kandidat tertentu. Hal ini dapat kita lihat lewat dua stasiun televisi berita terbesar di Indonesia yaitu Metro TV dan TV One. Melalui dua stasiun televisi tersebut terlihat sekali terdapat bias atau kecenderungan yang diperlihatkan dari kedua stasiun televisi dalam membuat tayangan pemberitaan bagi kedua pasangan kandidat capres-cawapres untuk pemilihan presiden 2014. Saat ini timbul kesan bagi masyarakat yang mendukung Joko Widodo cukup menonton saluran Metro TV dan bagi yang memfavoritkan Prabowo tinggal pilih saluran TV One saja.

Fenomena tersebut dapat terjadi karena afiliasi para kandidat dengan kedua media tersebut. Metro TV yang dimiliki oleh politisi Surya Paloh secara terang-terangan menjadi media yang mengkampanyekan pasangan Joko Widodo-Jusuf Kalla, sedangkan Tv One yang dimiliki oleh politisi Aburizal Bakrie menunjukan keberpihakannya kepada pasangan Prabowo-Hatta. Media framing yang dilakukan oleh kedua media tersebut membentuk opini politik tertentu di dalam masyarakat sebagai calon pemilih. Durasi, jumlah frekuensi serta kecenderungan obyek pemberitaan dapat menjadi alat propaganda yang digunakan kandidat untuk memperoleh dukungan. Hal ini sudah sangat melenceng dari peranannya sebagai media informasi dan sebagai pengontrol sosial. Meskipun demikian, menurut Scheufele media framing adalah hal yang tidak dapat dihindari dan natural terjadi dalam pembuatan suatu berita, terutama ketika pemilihan umum berlangsung. Namun demikian, di sisi lain media framing terkadang juga meningkatkan ketidakpercayaan dan sinisme masyarakat meskipun di sisi lain dipercaya mampu meningkatkan minat masyarakat dalam politik dikarenakan media dianggap mampu memberikan informasi yang mungkin belum diketahui oleh publik.

Menurut Entman (2008) pembentukan opini melalui media framing memiliki konsekuensi negatif bagi demokrasi karena stasiun televisi yang menayangkan isi siaran yang tidak netral dan hanya fokus terhadap pemberitaan atau isu-isu yang tidak substantif atau menampilkan kepentingan pribadi politisi (pencitraan) dan abai terhadap informasi politik yang lebih substansial seperti kebijakan para calon presiden atau kepala daerah maka dapat menggiring media menjadi tidak independen secara politik. Media yang tidak independen pada dasarnya dapat dihindari dengan menciptakan sebuah sistem persaingan media yaitu dengan mengembangkan keanekaragaman dalam pemilikan media. Persaingan yang terjadi diantara pemilik media dapat mendorong berbagai prespektif tentang kebijakan dan membatasi kekuasaan politik yang dimiliki oleh pemilik media sehingga pemberitaan menjadi lebih transparan.

Dalam pemilihan kepala daerah di tingkat lokal seperti pemilihan kepala daerah di Aceh juga diperlukan media yang independen yaitu media yang memberikan informasi yang benar, relevan, dan objektif bagi masyarakat sampai pada fungsi pengawas kekuasaan. Pengertian kekuasaan disini juga mencakup ruang lingkup yang cukup luas yang meliputi kegiatan politik, sosial, ekonomi, dan kebudayaan. Pada umumnya masyarakat menggunakan media sebagai sumber informasi untuk pemilihan umum. Sehingga peluang bagi penyalahgunaan media sebagai sarana "main mata" antara pemilik media dan elit politik daerah terbuka lebar. Mulai dari kesepakatan transaksioal untuk menyediakan space iklan politik, meliput pelantikan pejabat daerah hingga publikasi yang mem-blow up aktivitas kampanye pemilu. Kondisi ini lebih parah jika kebetulan pemilik media atau orang kuat di struktur organisasi media adalah salah satu kandidat yang mengikuti pemilihan. Media massa pada akhirnya hanya akan menjadi aparatus kepentingan sesaat guna menggalang suara konstituen di daerah pemilihan. 


\section{KESIMPULAN}

Peran media dalam panggung politik kontemporer semakin tidak tergantikan. Fenomena yang muncul adalah media telah menjadi perpanjangan tangan dari aktor-aktor politik yang bermain. Peran media kini melampaui apa yang bisa dikerjakan oleh partai politik melalui cara-cara konvensional. Bisa dilihat dari bagaimana elite-elite politik mengeluarkan wacana dan gagasan-gagasannya melalui media. Pada tahap tertentu, media sendiri juga telah menjelma menjadi aktor politik. Sebagai aktor politik, ia bisa mengeluarkan atau menahan sebuah isu yang menguntungkan maupun merugikan aktoraktor politik yang lain. Pembentukan opini publik pun pada akhirnya terjadi. Siapa yang memiliki akses atas media maka dia yang menguasai opini publik. Produk media dari berita, editorial, sampai iklan politik menjadi kanal menyalurkan ideologi pemilik dan jurnalisnya. Hal ini dapat dilihat di sejumlah media massa di Indonesia, baik cetak maupun elektronik.

Media yang telah bertransfromasi menjadi aktor politik tidak bergerak sendiri dalam memainkan peran tersebut karena pasti akan dibantu oleh kepentingan aktor-aktor politik dan pemilik modal atau mereka yang berlindung di balik topeng media untuk melakukan propaganda politik. Pada akhirnya, posisi media berada di tepi jurang, media menjadi tidak lagi independen karena kebebasan mengkritik dan menyampaikan pendapat beralih menjadi kebablasan informasi yang bersandar pada kemauan pemilik media. Hal ini dapat dilihat ketika pemilihan umum berlangsung. Media berdiri di dua perahu yaitu berpihak pada kepentingan politik dan di sisi lain berpihak pada kepentingan pemilik media. Pengalaman pemilihan presiden 2014 menunjukkan fenomena terbelahnya media besar di Indonesia menjadi dua kubu. Pemberitaan menjadi simpang-siur mengikuti selera pemilih media masing-masing. Secara tidak langsung, pembelahan media menjadikan masyarakat terpaksa mencari kebenaran informasi diantara kesimpangsiuran berita yang ada.

Media seharusnya menjadi sarana pencerahan dan transformasi nilai-nilai kebenaran terutama kebenaran politik agar masyarakat dapat melihat fakta secara apa adanya. Media sebaiknya tidak memunculkan kesan menilai atau keberpihakan khususnya dalam masa kampanye pemilihan umum. Biarkan masyarakat sendiri yang akan menilai. Yang diperlukan media hanyalah menyampaikan informasi yang sebenarnya, jelas hitam putihnya. Sehingga masyarakat tidak terjebak pada pilihan yang diciptakan media dan media pada akhirnya harus mampu bersikap objektif dalam penayangan berita politik dan bertindak independen.

\section{DAFTAR PUSTAKA}

Berger R. Charles dkk. 2015. Handbook of Ilmu Komunikasi. Bandung: Nusamedia

Berger, Peter L., Luckmann, Thomas. 1990. Tafsir Sosial atas Kenyataan: Risalah Tentang Sosiologi Pengetahuan. Penerjemah Hasan Basri. Jakarta: LP3S.

Cook, Timothy E. 1998. Governing with the News: the News Media as a Political Institutio.Chicago: Chicago University Press.

Eriyanto. 2005. Analisis Framing: Konstruksi, Ideologi, dan Politik Media. Yogyakarta: LkiS.

Ghazali, Effendi dan Hidayat N, dkk. 2000. Pers dalam Revolusi Mei: Runtuhnya sebuah Hegemoni. Jakarta : Gramedia Pustaka Utama. 
Graber, Doris A. 1990. Media Power in Politics. Second edition. Washington: Congressinal Quarterly Press.

Habermas, Jürgen. 2015.Ruang Publik. Yogyakarta: Kreasi Wacana.

Hamid, Ibnu. 2004. Konstruksi Relaitas Politik Dalam Media Massa. Jakarta: Granit.

Heywood, Andrew. 2013. Politik. Yogyakarta: Pustaka Pelajar.

Hidayat, Dedy Nur. 1997. Pardigma dan Perkembangan Penelitian Komunikasi. Jurnal ISKI, Menuju Paradigma Baru Penelitian Komunikasi. Bandung: PT Remaja Rosdakarya.

Koike, Makato. 2002. Globalizing Media and Local Society in Indonesia, makalah dalam workshop 13-14 September 2002. Leiden, Nederland, dalam IIAS News.

Littlejohn, W. Stephen. 2002. Theories of Human Communication, California: Wadsworth Publishing Company.

McQuail, Dennis. 1987. Communication Theory: An Introduction. London: SagePublication.

Moelong, Lexy. 1993. Metodelogi Penelitian Kualitatif. Bandung: PT Remaja Rosdakarya.

Muis, A. 2000. Titian Jalan Demokrasi: Peranan Kebebasan Pers untuk BudayaKomunikasi Politik. Jakarta: Kompas.

Neumann, A. Lin. 1998. Freedom takes hold: ASEAN Journalism in Transition. New York:Committee to Protect Journalist.

Nimmo, Dan. 2000. Komunikasi Politik. Bandung: Remaja Rosda Karya.

Oetama, Jakob. 2001. Pers Indonesia: Berkomunikasi dalam Masyarakat Tidak Tulus. Jakarta: Penerbit Kompas.

Rahmat, Saleh. 2004. Potensi Media Sebagai Ruang Publik. Jurnal Penelitian Ilmu Komunikasi. Jakarta.

Rivers, William L. 2003. Media Massa dan Masyarakat Modern. Yogyakarta: Prenada Media.

Rusadi, Udi. 2002. Diskursus Kerusuhan Sosial Dalam Media Massa. Jakarta: Universitas Indonesia.

Salvatore, Simarmata. 2004. Media dan Politik. Jakarta : Yayasan Obor.

Subiakto, Henry. 2014. Komunikasi Politik, Media, Dan Demokratisasi. Jakarta: Kencana. 